\title{
Distribution of $\mathrm{ABO}$ and rhesus blood groups among selected tribes in Adamawa State, Nigeria
}

\begin{abstract}
Background/objective: Prevalence of $\mathrm{ABO}$ and Rhesus blood groups varies from tribe to tribe. This study aims to examine the distribution of $\mathrm{ABO}$ and Rhesus blood group among selected tribes in Adamawa State, Nigeria.
\end{abstract}

Materials and methods: $\mathrm{ABO}$ and Rhesus phenotyping was carried out using standard tube technique.

Result: Of the 654 subjects tested, 368(56.2\%) were of blood group O, 139(21.3\%) were blood group $\mathrm{B}$, while $116(17.7 \%)$ and $31(4.7 \%)$ were group $\mathrm{A}$ and $\mathrm{AB}$ respectively. $577(88.32 \%)$ were Rhesus D positive while $77(11.79 \%)$ were Rhesus D negative. When comparing $\mathrm{ABO}$ blood group distribution among tribes, $\mathrm{O}$ blood group was higher among the Kilba tribe $(4.74 \%)$ at $\mathrm{P}<0.05$ compare to other tribes. Bura tribe had the highest $\mathrm{AB}$ blood group of $1.53 \%$, the A blood group was more in Tangale tribe with $2.60 \%$ while B blood group was predominant in Wurkun tribe $(3.67 \%)$ $\mathrm{P}<0.05$. Kanuri tribe had the highest percentage (5.97\%) of Rhesus ' $\mathrm{D}$ ' negative blood group while Fulani, Vere, Hausa and Waja tribes had 2.14\%, 2.60\%, $0.31 \%$ and $0.77 \%$ of Rhesus D negative blood respectively.

Conclusion: In Adamawa state, Gene frequencies with respect to the $\mathrm{ABO}$ system shows a formula $\mathrm{O}>\mathrm{B}>\mathrm{A}>\mathrm{AB}$ indicating high prevalence of ' $\mathrm{O}$ ' blood group and a predominance of allele B over allele A. Information obtained in this study will help in the optimum selection of blood type and blood products in Blood banking as well as facilitate the formulation of relevant blood banking and transfusion policies in this locality.

\author{
Volume 4 Issue 6 - 2017
}

\author{
Emmanuel A Etim,' Josephine O Akpotuzor, ${ }^{2}$ \\ Adjekuko C Ohwonigho, ${ }^{3}$ Francis AA \\ 'Federal Medical Centre, Nigeria \\ ${ }^{2}$ Faculty of Medical Laboratory Science, University of Calabar, \\ Nigeria \\ ${ }^{3}$ Department of Medical Laboratory Services, General Hospital \\ Okwe-Asaba, Nigeria
}

Correspondence: Emmanuel A Etim, Federal Medical Centre, Yola,Adamawa State, Northeast Nigeria, Tel +2348063924735, Emailemmasuti@yahoo.com

Received: April 10, 2017| Published: June 22, 2017

\section{Introduction}

Classification of blood into groups is based on the presence or absence of inherited oligosaccharides antigenic substances on the surface of the red blood cells. ${ }^{1}$ Blood groups are genetically determined and it exhibit polymorphism in different populations. Up to 30 blood groups have been identified in human beings base on the type of antigen present on the surface of the red blood cells. ${ }^{2}$ The human red blood cell membrane is complex and contains many blood group antigens, the most clinically important being the $\mathrm{ABO}$ and the Rhesus antigens ${ }^{3}$ this is because of the occurrence of antibodies of these blood group systems and ability of antibodies of the blood group systems to cause hemolytic transfusion reaction and hemolytic disease of the newborn. The Rhesus blood group system is more complex than the $\mathrm{ABO}$ system and comprises upto 54 antigens but the $\mathrm{D}$ antigen remains the most clinically important within the Rhesus system. ${ }^{4}$ The $\mathrm{ABO}$ blood group are controlled by a single gene located on the long arm of the chromosome 9 with 3 alleles and $\mathrm{ABO}$ genes located in chromosome 9q34.1-q34.2(6-9) consists of 7 exons distributed over $18 \mathrm{~kb}$ of genomic DNA. ${ }^{5} \mathrm{ABO}$ and Rhesus blood groups are the most investigated blood group system in man, and because of the ease of identifying their phenotypes, they have been used as genetic markers of populations. ${ }^{6}$ It is well reported that differences in distribution of ABO blood groups exist, both within and among tribal groups of diverse geographical areas of the world. ${ }^{3,7-10}$ Some variations may even occur within small regions. ${ }^{11}$ In Nigeria, The pattern of distribution of the $\mathrm{ABO}$ and Rhesus blood varies from region to region as reported in Ogbomosho, south-west region, ${ }^{12}$ Niger Delta, south-south region, ${ }^{13}$
Gusau, North-west region. ${ }^{14}$ However, the $\mathrm{ABO}$ and Rhesus blood distribution in Adamawa state, North-east region of Nigeria have not yet been fully elucidated hence the need for this study.

The people of Adamawa state belong to the North east geopolitical zone/region of Nigeria. Adamawa state was created in August 1991 from the defunct Gongola State and occupies about 38000 square kilometers with a population of 3178950 according to 2006 census. ${ }^{15}$ The state capital is Yola and there are over 78 tribes in Adamawa state. Some of the tribes includes: Fulani, Kilba, Chamber, Kanuri, Gude, Waja, Vere, Tangale, Wurkun, Michika, Bura, Tera, Sawa, Mafa, Margi, Hausa and Yungur. The type of blood and blood products available in the hospital blood bank in a particular community should ideally correlates with the pattern of distribution of clinically important red cell antigen in the general population of that community, ${ }^{16}$ hence this study aims at providing information on $\mathrm{ABO}$ and Rhesus blood groups distribution in Adamawa state and would also help in formulation of blood transfusion policies in this locality.

\section{Materials and methods}

This study was carried out in Emicare Medical Laboratory in Yola Adamawa, North Eastern Nigeria. All participants gave their informed consent prior to their inclusion in this present study. Blood samples were collected from all subjects by venipuncture into plain sample bottles for the determination of $\mathrm{ABO}$ blood and Rhesus blood groupings. $\mathrm{ABO}$ cell and serum grouping was carried out within two hours of blood collection. A drop of anti-A, anti-B, and anti-AB each was placed in clean test tubes labeled 1,2 , and 3 and to each tube was 
added a drop of $5 \%$ red blood cell suspension in saline. The content were gently mixed together and allowed to stand at room temperature for $1 \mathrm{hr}$ after which they were examined for agglutination. For the serum grouping, a drop of 5\% A cells, B cells, and O cells were placed in a clean test tubes labeled 1,2 , and 3 and to each tube was added a drop of subject's serum. The contents were gently mixed together and allowed to stand at room temperature for $1 \mathrm{hr}$ after which they were examined for agglutination. All negative results are confirmed microscopically. For the Rhesus grouping, A drop of seraclone anti-D (RH1) was placed in clean labeled test tube and a drop of 5\% RBC suspension in saline of the subject was then added and incubated at $37^{\circ} \mathrm{C}$. At the end of the incubation periods, the contents of the tube were mixed gently and centrifuged for 30 seconds at $1000 \mathrm{~g}$. Agglutination was read macroscopically and microscopically. All negative or weakly reacting results were confirmed using the indirect antiglobulin test (IAT) procedure.

\section{Results}

Of the 654 subjects tested, $56.2 \%$ were of blood group O, $21.3 \%$ were group B, $17.7 \%$ were group A and $4.7 \%$ were in group $\mathrm{AB}$ as in Table 1 . In addition, $88.2 \%$ of the studied population was Rhesus D positive while $11.8 \%$ were Rhesus D negative as shown in Table 2. When comparing the distribution of $\mathrm{ABO}$ blood groups based on tribes in Table 3, Prevalence of $\mathrm{O}$ blood group was significantly higher among the Kilba tribe $(4.74 \%) \mathrm{P}<0.05$ compare to other tribes. The Bura tribe had the highest number of people with $\mathrm{AB}$ blood group of $1.53 \%$, the A blood group was more in Tangele tribe (up to $2.60 \%$ ). $\mathrm{B}$ blood group was predominant in Wurkun tribe (3.67\%) $\mathrm{P}<0.05$. Similarly Rhesus blood group distribution was compared among the tribes. Kanuri tribe had the highest percentage of Rhesus negative blood group of $5.97 \%$ while Vere, Fulani and Waja tribes had 2.60\%, $2.14 \%$ and $0.77 \%$ of Rhesus negative blood respectively as shown in Table 4. $0.31 \%$ of the Hausa tribe was Rhesus D negative.

Table I Prevalence of $A B O$ blood group among the studied population in Adamawa state

\begin{tabular}{lllll}
\hline $\begin{array}{l}\text { ABO blood } \\
\text { group }\end{array}$ & 'O' & 'B' & 'A' & 'AB' \\
\hline Prevalence & $368(56.2 \%)$ & $139(21.3 \%)$ & $116(17.7 \%)$ & $31(4.7 \%)$ \\
\hline
\end{tabular}

Table 2 Prevalence of rhesus antigen among the studied population in Adamawa state

\begin{tabular}{ll}
\hline Rhesus 'D' positive & Rhesus 'D' negative \\
\hline $577(88.2 \%)$ & $77(11.8 \%)$ \\
\hline
\end{tabular}

Table 3 Prevalence of ABO blood among tribes in Adamawa State

\begin{tabular}{|c|c|c|c|c|}
\hline Tribes/prevalence blood group & 'O' blood group & 'B' blood group & 'A' blood group & 'Ab' blood group(\%) \\
\hline Fulani & $12(1.84 \%)$ & $04(0.6 \%)$ & $15(2.30 \%)$ & $07(1.07 \%)$ \\
\hline Kilba & $31(4.74 \%)$ & $03(0.46 \%)$ & $05(0.77 \%)$ & \\
\hline Chamba & $27(4.13 \%)$ & $05(0.77 \%)$ & $07(1.77 \%)$ & \\
\hline Kanuri & $23(3.52 \%)$ & $03(0.46 \%)$ & $05(0.77 \%)$ & $7(1.07 \%)$ \\
\hline Gude & $29(4.44 \%)$ & $04(0.61 \%)$ & $06(0.92 \%)$ & \\
\hline Vere & $27(4.13 \%)$ & $04(0.61 \%)$ & $08(1.22 \%)$ & \\
\hline Tangale & $10(1.53 \%)$ & $12(1.84 \%)$ & $17(2.60 \%)$ & \\
\hline Wurkun & $10(1.53 \%)$ & $24(3.67 \%)$ & $05(0.77 \%)$ & \\
\hline Michika & $27(4.13 \%)$ & $08(1.22 \%)$ & $03 / 4(0.46 \%)$ & \\
\hline Bura & $10(1.53 \%)$ & $12(1.84 \%)$ & $07(1.07 \%)$ & $10(1.53 \%)$ \\
\hline Tera & $28(4.28 \%)$ & $04(0.61 \%)$ & $07(1.07 \%)$ & \\
\hline Waja & $23(3.52 \%)$ & $07(1.07 \%)$ & $8(1.22 \%)$ & \\
\hline Sawa & $24(3.67 \%)$ & $07(1.07 \%)$ & $07(1.07 \%)$ & \\
\hline Mafa & $29(4.44 \%)$ & $04(0.61 \%)$ & $0 \mathrm{Ol}(0.15 \%)$ & $5(0.77 \%)$ \\
\hline Margi & $19(2.91 \%)$ & $15(2.30 \%)$ & $04(0.61 \%)$ & \\
\hline Hausa & $19(2.10 \%)$ & $15(2.30 \%)$ & $04(0.61 \%)$ & \\
\hline Yungur & $20(3.06 \%)$ & $08(1.22 \%)$ & $07(1.07 \%)$ & $2(0.30 \%)$ \\
\hline Total & $368(56.2 \%)$ & $139(21.3 \%)$ & $116(17.7 \%)$ & $3 I(4.7 \%)$ \\
\hline
\end{tabular}


Table 4 Prevalence of rhesus antigen among tribes in Adamawa state

\begin{tabular}{lll}
\hline Tribes & Rhesus positive & Rhesus negative \\
\hline Fulani & $92(14.08 \%)$ & $14(2.14 \%)$ \\
Kilba & $40(6.12 \%)$ & \\
Chamba & $34(5.20 \%)$ & \\
Kanuri & $35(5.36)$ & $39(5.97 \%)$ \\
Gude & $29(4.44 \%)$ & \\
Vere & $12(1.84 \%)$ & $17(2.60 \%)$ \\
Tangale & $40(6.12 \%)$ & \\
Wurkun & $52(7.96 \%)$ & \\
Michika & $12(1.84 \%)$ & \\
Bura & $40(6.12 \%)$ & \\
Tera & $17(2.60 \%)$ & \\
Waja & $35(5.36 \%)$ & $5(0.77 \%)$ \\
Sawa & $12(1.84 \%)$ & \\
Mafa & $29(4.44 \%)$ & \\
Margi & $23(3.52 \%)$ & \\
Hausa & $40(6.12 \%)$ & \\
Yungur & $35(5.36 \%)$ & \\
Total & $577(88.32 \%)$ & \\
\hline & & \\
\end{tabular}

\section{Discussion}

Among the tribes in Yola, it was observed that, there is variation in the $\mathrm{ABO}$ and Rhesus blood group distribution. Gene frequencies with respect to the $A B O$ system for this present study has shown a general formula $\mathrm{O}>\mathrm{B}>\mathrm{A}>\mathrm{AB}$ indicating large prevalence of group $\mathrm{O}$ blood and a preponderance of allele $\mathrm{B}$ over allele $\mathrm{A}$ in the studied population. From the result obtained, a large percentage (56.2\%) of the studied population lacks both the A and B antigen on the surface of the red cell. This implies that, among the tribes in Yola the gene that codes for the A and B red cell surface antigen is absent in $56.2 \%$ of the population. Kilba tribe had the highest prevalence of blood group $\mathrm{O}$ which indicates that most people from Kilba tribe lacks the gene that codes for A and B antigen of the red cell surface and therefore in looking for group $\mathrm{O}$ blood especially in emergency, persons from Kilba tribe could be considered first and people from Kilba tribe in Yola are likely to reject transfusion of A and B blood because they have anti-A and anti-B antibody in their blood stream since the lack both antigen A and antigen B on the surface of their red cells. However, the result obtain from this study indicates that unlike Kilba tribe, people from the Bura tribe were predominantly of the blood group $\mathrm{AB}$. This indicates that people from Bura tribe have both the $\mathrm{A}$ and $\mathrm{B}$ antigens on the surface of their red blood cell and therefore they lack anti-A and anti-B antibody in the their blood stream and people from Bura tribe are more likely to survive transfusion 'A' or, 'B' blood group. From this study also, it was observe that the A red cell antigen was predominant in Tangele tribe compare to other tribes and this goes to show the gene that codes for A antigen on the surface of the red cell is more in Tangele tribe and that people from Tangele tribe are more likely to reject blood group B for transfusion because of the presence of anti-B antibody in their blood, but they may be successfully transfuse with A or O blood in case of emergency since they lack anti-A antibody. However, of the 654 subject that was tested, the Wurkun tribe in Adamawa state had the highest prevalence of B antigen on the surface of the red cell. This indicates that the gene that codes for the B antigens on the surface of the red cell is more among Wurkun tribe when compare to other tribes in Adamawa state. The high prevalence of group $\mathrm{O}$ observed in this present study among the tribes of yola in North eastern Nigeria has an advantage particularly in terms of optimizing the use of blood resources stock in emergency situations because blood group $\mathrm{O}$ individuals lack $\mathrm{ABO}$ blood group antigens on their red cell and thus are termed universal donors. Such blood can be transfused to patients of blood groups $\mathrm{A}, \mathrm{B}$ and $\mathrm{AB}$ in emergency. However, there is a caveat to this rule and some level of caution need to be exercised because, the serum of some blood group O blood individuals may contain $\alpha$ and $\beta$ haemolysins. Ideally only group $\mathrm{O}$ blood which is negative for high titer haemolysin should be given to groups $\mathrm{A}, \mathrm{B}$, and $\mathrm{AB}$ individuals in emergency situations, when $\mathrm{ABO}$ group specific units are not immediately available.

Our finding is however at variance with previous reports in other parts of Nigeria. A prevalence pattern of $(O>A>B>A B)$ have been reported among residents of African descent in Port Harcourt, Niger Delta, among the Yoruba and Hausa ethnic groups, in five zone of Nigeria and in Ibadan respectively. ${ }^{17-20}$ In this study, Rhesus positive blood was predominant in most the tribes in Adamawa state. $11.8 \%$ of Rhesus D negative observed in our study and there are several obstetric connections associated with the prevalence of Rhesus D-negative blood among tribes in Adamawa state because antibody produced by Rhesus D negative individuals as a result of exposure to Rhesus D antigens has serious clinical implications including hemolytic disease in the newborn and/or transfusion reactions. The finding in the present study with respect to pattern of distribution of Rhesus D antigen is similar to previous reports obtained among tribes in other parts of Nigeria. For instance in the Niger Delta region of Nigeria is observed that $93 \%$ of subjects were Rhesus positive while the remaining $7 \%$ of the study population were negative. ${ }^{17}$ Similarly, 96.7\% Rhesus D positive rate has been recorded among the Ibos ethnic group of Eastern Nigeria. $^{21}$

\section{Conclusion}

In this present study we observed that the prevalence of $\mathrm{ABO}$ blood groups varies from tribe to tribe and gene frequencies with respect to the $\mathrm{ABO}$ system has shown a general formula of $\mathrm{O}>\mathrm{B}>\mathrm{A}>\mathrm{AB}$ indicating high prevalence of $\mathrm{O}$ blood group and a predominance of allele B over allele A in Adamawa state. $88.2 \%$ were Rhesus D positive while $11.8 \%$ were Rhesus $\mathrm{D}$ negative. Information obtained in this study will help in the optimum selection of blood type storage and blood products in Blood banking in Adamawa state as well as facilitate the formulation of relevant blood banking and transfusion policies in Northeastern Nigeria.

\section{Acknowledgements}

The author wishes to acknowledge all the subjects included in this study for their collaboration. We are also grateful to management and staffs of the Emicare Medical laboratory Yola Nigeria.

\section{Conflict of interest}

The author declares no conflict of interest.

\section{References}

1. Mohamad S Jaff. ABO and rhesus blood group distribution in Kurds. $J$ Blood Med. 2010;1:143-146. 
2. International Society of Blood Transfusion (ISBT) Table of blood group systems. USA; 2008.

3. Mourant AE, Kopec AC, Damaniewssta-Sobczak K. Distribution of Human blood groups and other polymorphism. 2nd ed. USA: Oxford University Press Northern and central Europe; 1976. p. 62-69.

4. Joyce Poole Blood Group Incompatibility. Bristol, UK: International Blood Group Reference Laboratory; 2001. p. 1-7.

5. Yamamoto F, McNeill PD, Hakomori S. Genomic organization of human histo-bloodgroup ABO genes. Glycobiology. 1995;5(1):51-58.

6. Reid ME, Lomas-Frances C, Martin Olsson. The Blood Group Antigen Facts Book. SanDiego, USA: Academics Press; 1997. p. 12-16.

7. Bashwari LA, Al-Mulhim AA, Ahmad MS, et al. Frequency of ABO blood groups in the eastern region of Saudi Arabia. Saudi Med J. 2001;22(11):1008-1012.

8. Mondal B, Maiti S, Biswas BK, et al. Prevalence of hemoglobinopathy, $\mathrm{ABO}$ and rhesus blood groups in rural areas of West Bengal, India. $J$ Res Med Sci. 2012;17(8):772-776.

9. Khan MN, Khaliq I, Bakhsh A, et al. Distribution of ABO and Rh D blood groups in the population of Poonch District, Azad Jammu and Kashmir. East Mediterr Health J. 2009;15(3):717-721.

10. Hamed CT, Bollahi MA, Abdelhamid I, et al. Frequencies and ethnic distribution of $\mathrm{ABO}$ and $\mathrm{Rh}(\mathrm{D})$ blood groups in Mauritania: results of first nationwide study. Int J Immunogenet. 2012;39(2):151-154.

11. Agarwal N, Thapliyal RM, Chatterjee K. Blood group phenotype frequencies in blood donors from a tertiary care hospital in North India Blood Res. 2013;48(1):51-54.
12. Bakare AA, Azeez MA, Agbolade JO. Gene frequencies of ABO and Rhesus blood groups and haemoglobin variants in Ogbomosho, SouthWest, Nigeria. Global J Med Sci. 2004;3(3):17-22.

13. Egesie UG, Egesie OJ, Usar I, et al. Distribution of ABO, Rhesus blood groups and haemoglobin electrophoresis among the undergraduate students of Niger Delta University Nigeria. Niger J Physiol Sci. 2008;23(1-2):5-8.

14. Erhabor O, Isaac IZ, Saidu A, et al. The Distribution of ABO and rhesus blood groups among residents of Gusau, Zamfara State, North Western Nigeria. J Med Health Sci. 2013;2319-9865.

15. JI Onu, Z Abayomi. An analysis of poverty among households in Yola metropolis of Adamawa State, Nigeria. J Soc Sci. 2009;20(1):43-48.

16. Judd JW. Methods in Immunohematology. 2nd ed. Durham, USA: Montogomery scientific Publications; 1994.

17. Jeremiah ZA. Abnormal haemoglobin variants, ABO and Rh blood groups among student of African descent in Port Harcourt, Nigeria. Afr $J$ Health Sci. 2006;6(3):177-181.

18. Omotade OO, Adeyemo AA, Kayode CM, et al. Gene frequencies of $\mathrm{ABO}$ and $\mathrm{Rh}$ (D) blood group alleles in a healthy infant population in Ibadan, Nigeria. West Afr J Med. 1999;18(4):294-297.

19. Worlledge S, Ogiemudia SE, Thomas CO, et al. Blood group antigens and antibodies in Nigeria. Ann Trop Med Parasitol. 1974;68(3):249-264.

20. Falusi AG, Ademowo OG, Latunji CA, et al. Distribution of ABO and RH genes in Nigeria. Afr J Med Med Sci. 2000;29(1):23-26.

21. Ukaejiofor EO, Okonkwo WC, Tagbar EN, et al. Blood Transfusion in the Tropics. Nigeria: Salem Press $\mathrm{ABO}$ and Rhesus in a Nigerian population; 1996. p. 1-22. 